\title{
稲作と飼料作の受託組織の間の競争と連携
}

\author{
一構成員のインフォーマルな活動とその機能一
}

東城眞治

\section{The Competition and Cooperation among Organizations for Contract Farming and the Function of Informal Activities}

\author{
Shinji Tojo (Toyama Prefectural Government)
}

The authorities concerned have attempted to promote the cooperation among organizations for contract farming in rice and feed and forage crops production. However, most have failed. The reason are as follows: Firstly, it is difficult to consider the cooperation without avoiding the competition for contracting farmland among the organizations. Secondly, since agricultural production heavily depends on the weather, it is apt for the farmers in cooperation to conflict each other.

The key whether we can resolve the aforementioned problem or not depends on the potential of energy stemed from daily social relations such as friendship and kinship. Therefore, we must pay attention to farmers' informal activities based on the daily social relations. The informal activities have remarkable effects on the operation and management of an organization and the relation among organizations in the following three phases:

when a series of cooperation is developed by a part of members of an organization, the energy makes up the deficiency of functions of the organization in the manner which reduces the occurrence of conflicts in the organization;

when a series of cooperation is developed beyond an organization, even if the organizations compete each other, the energy reduces the intensification of competition and leaves the door open for cooperation in the manner which prevents from the occurrence of conflicts among the organizations ;

and when a series of cooperation developed beyond an organization is combined with that in the organization, even if the organizations compete, the energy amplified by the combination makes the group cooperation and its continuation possible.

\section{1. 課題と方法}

現在各地ですすめられている地域農政のねらいは， 地域内の農地，農業労働力，農業機械，さらには中間 生産物などを有效利用し，地域農業所得を向上させる ことにある，その際に重要なのは，それを担う農家の 組織化と，それら生産組織の連携が促進されることで あり，特に異作目の間においてである. それとと屯 に,「競争原理」の導入は生産性の高い農業経営の実現 とそれらが競争するととによる地域農業所得の向上を 考えれば重要なととと思われる.すなわち，異作目の 生産組織の間の関係は連携のみでなく, 競争の展開に あ配慮するととが重要となる。

経営分化がすすむ稲作地帯で, 水田酪農のメリット を生かすためには稲作経営と酪農経営の連携が要とな

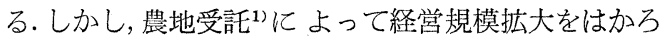

うとする稲作の受託生産組織と酪農経営によって作ら れる飼料作の受託生産組織の間でみた場合, 行政当局 や農協などがその連携を強力にすすめようとしても, 農地の厳しい受託獲得競争のみの展開であったり, 連 携がおてなわれても継続しないのが大部分である2).

その要因の第一は, 稲作や飼料作の受託生産組織は 経営規模拡大に必要とする面積が大きいととから, 農 地の受託獲得競争が発生, 拡大しやすいとと. 近年, 多くの地域で農地の受委託面積の増加が目立ってきて いるが，その一方では農協を中心にした集落ぐるみの 農業生産組織づくりへの取組みが始められ, 徐々に, その効果を上げている，てのような取組みの進展によ って，すでに確保してきたテリトリーを失うのではな いか. このととは彼らの大きな関心事となり，テリト リーをいかに維持していくかに大きな経営努力が払わ れ，農地の厳しい受託獲得競争が展開されているのに 
かわりがない33．その際に当事者間の信頼関係が大き な競争要素となることから関係機関が農地の受委託や 受託農地の相互交換を促そうとしても限界が否めな い. 第二に，関係機関が，多種多様にわたる生産諸要 素の相互交換を促進しようと，それぞれの交換価值の 相場を設定し，等価交換をねらっても，不順な天候に よって不定時，不定量な交換を強いられやすいとと. さらに，不順な天候は飼料作後やきゅう肥施用後の水 稲栽培にも影響し，倒伏や減収のリスクが大きくなる ことがあげられる.

このような現実の問題から連携が難しいのである が，その必要性は大きくなってきている，すなわち， 稲作の受託生産組織は米価不振のなかで，より収益を 上げるための有機米生産に取組んだり, 水稲, 大麦, 大豆の収量が年次的に変動することに対して水田地力 の維持, 向上を図ろう之, 酪農経営との連携を求める 傾向が強くなってきている. しかし，上述のような現 実の問題加ら，彼らの間の連携促進汇対する「関保機 関による取組み」が不十分にならざるをえないとすれ ば，その連携を促したり，たとえ現時点で連携がおて なわれなくても，競争関係が決定的なものに陥らず， 今後の連携の余地方残されるような機能を別の側面に 見い出すととも重要と思われる。 その際に注目される のが，農業生産組織にみられる構成員と組織体との特 徵的な関係である.

すなわち，多くの農業生産組織では，その構成員は 対等の立場で参加し, 組織体に求める誘因屯多種多様 である.にあかかわらず，組織体が構成員に与える誘 因は決して大きくはない，一方，乙れらの構成員は， 生産組織に参加する以前にしばしば濃厚な日常生活的 な社会関係をむっている。乙のために, 組織体から得 られる誘因が不足しがちになった場合には，親しい間 柄の構成員は組織体内部で，適宜，グループを作り， グループとして対応をはかったり, 他の組織体に属す る親しい間柄の構成員にも連携を求めたりする.

このような構成員の特徴的な活動が組織体自身の運 営，管理や組織体の間の関係におよぼす機能に積極的 な意義を見い出そうとする場合，一般経営学ですすめ られてきた「インフォーマルな活動関する研究」が有 効な示唆を与えてくれる4). 農業分野で活用するてと の重要性は金沢らによってすでに指摘されているが, 実証的な研究が殆どない5).

本稿では，農業者のフォーマルとインフォーマルな 活動を次のように整理する. 構成員に共通する目的に
図 1 構成員のインフォーマルな活動と組織体 並びそ組織体の間の関係

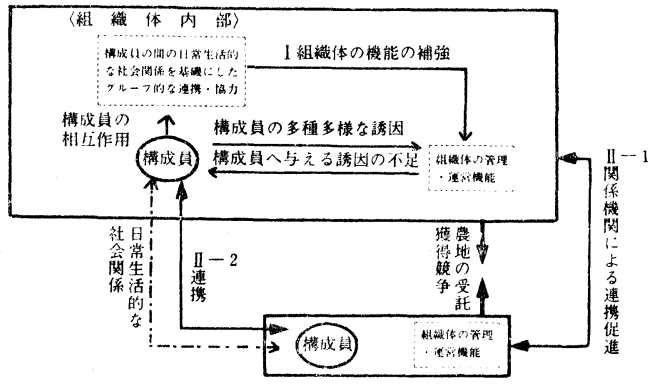

そって，組織体自身の運営，管理や組織体の間の連携 がすすめられようとする際に, 各構成員の活動が共通 の目的にそって意識的に調整されることが必要とな る. その際における構成員の活動がフォーマルな活動 である．一方，構成員に共通する目的にそって意識的 に調整されたものでなく，日常生活的な社会関係を基 礎にして, 組織体の内部や組織体を越えて他の組織体 の構成員と結びついている小グループもみられる.と のような構成員の間の日常生活的な社会関係を基礎に した構成員の活動がインフォーマルな活動である。乙 の活動は農業生産上の活動之融合し, 組織体自身の運 営，管理や組織体の間の連携に影響をおよぼすととに なる。

分析の枠組みを設定するにあたって，構成員の活動 の範囲を，図1のような組織体内部之他の組織体との 間という二つの局面でわける．まず，前者の場合につ いて, 現実の多くの組織体では, 図 1 のI のように, 構成員がその誘因を満たし切れなかったり，あるいは できるだけ満たそうと工夫する局面に执いて，日常生 活的な社会関係を基礎にして，適宜，グループを作る ことが多い. 結果的に，乙のような構成員のインフォ 一マルな活動は, 組織内グループのかたちで, 組織体 自身の機能不足を補強することになる。

次に, 後者の場合である ${ }^{6}$. 異作目の農業生産組織 の間の連携を促す機能の一つは, 図 1 のーー1に示す 関保機関に求められること. 例えば, 稲作と飼料作の 受託生産組織の連携によって農地の高度利用を促そう 之する場合, 試験研究や普及機関は水田輪作技術の開 発と普及に努め, 行政当局は農地の高度利用に奖励金 を追加するなどして, 連携を促す. しかし, 農地の厳 しい受託獲得踥争が展開されるなかで連携を促進する には，これら関係機関の働きのみでは不十分な場合が 多い. 
表 1 稲作の分析事例の概要

\begin{tabular}{|c|c|c|}
\hline 組 織 名 & 農 & 園 \\
\hline 発 足 年 & 1973 年 & 1971 年 \\
\hline 䋘 形 & 共 同 経 営 & 個 別 経 営 \\
\hline 区 & 若 林 地 区 & 出 町 地 区 \\
\hline 構 成 員 (年令) & 3 人 $(48 、 38 、 36 才)$ & 経営主と妻（44、41才） \\
\hline 常 時 㕍 用 者 & 男子 2、女子 1人 & 男子 3 、女子 1 人 \\
\hline 営 面 & 自作地 5.1 、受託農地 $44.7 \mathrm{ha}$ & 自作地 $1.2 、$ 受託農地 $49.1 \mathrm{ha}$ \\
\hline 主な部分作業受託 & 耕耘 23.3 、对取 $12.8 \mathrm{ha}$ & 耕耘 20.3 、刏取 $13.0 \mathrm{ha}$ \\
\hline 作 付 内 & 水稲 41.8 、大麦 8.0 、大豆 $8.0 \mathrm{ha}$ & 水稲 38.5 、大麦 12.1 、大豆 $6.5 \mathrm{ha}$ \\
\hline 主要な機械・施設装備 & $\begin{array}{l}\text { トラクタ } 5 \text { 台、乗用田植機 } 2 \text { 台、自脱型コンバ } \\
\text { イン } 4 \text { 台、乾橾調製施設 } 1 \text { 棟 }\end{array}$ & $\begin{array}{l}\text { トラクタ } 4 \text { 台、乘用田植㙨 } 2 \text { 台、自脱型コンバ } \\
\text { イン } 3 \text { 台、乾燥調製施設 } 1 \text { 棟 }\end{array}$ \\
\hline
\end{tabular}

注：1986年時点の実態による.

表 2 飼料作の分析事例の概要

\begin{tabular}{|c|c|c|c|c|c|c|c|c|c|c|c|c|c|c|c|}
\hline \multicolumn{3}{|c|}{ 組 織 名 } & \multicolumn{6}{|c|}{ C 飼料 作組 合 } & \multicolumn{7}{|c|}{ D 飼 料 作組 合 } \\
\hline 足 & 年 & & \multicolumn{6}{|c|}{1974 年 } & \multicolumn{7}{|c|}{1975 年 } \\
\hline 構 & 成 & 員 & \multicolumn{6}{|c|}{$\begin{array}{l}6 \text { 名 } \\
(\mathrm{C} 1, \mathrm{C} 2, \mathrm{C} 3, \mathrm{C} 4, \mathrm{C} 5, \mathrm{C} 6)\end{array}$} & \multicolumn{7}{|c|}{$\begin{array}{l}5 \text { 名 }(\mathrm{d} 1 、 \mathrm{~d} 3 、 \mathrm{~d} 4 、 \mathrm{~d} 6 、 \mathrm{~d} 7) \mathrm{d} 2 \text { が } 1983 \text { 年、 } \mathrm{d} 5 \text { が } \\
1984 \text { 年に酪鹿を廃止し、組合を脱退 }\end{array}$} \\
\hline \multicolumn{3}{|c|}{ 主要な機械・施設装備 } & \multicolumn{6}{|c|}{$\begin{array}{l}\text { トラクタ5台、へイベーラ2、モアコン } \\
\text { ティショナー2、ロールベーラ3 }\end{array}$} & \multicolumn{7}{|c|}{$\begin{array}{l}\text { トラクタ } 3 \text { 台、ヘイベーラ2、モアコンディショナ } \\
-2\end{array}$} \\
\hline 構 & 成 & 員 & $\mathrm{C} 1$ & $\mathrm{C} 2$ & $\mathrm{C} 3$ & $\mathrm{C} 4$ & $\mathrm{C} 5$ & $\mathrm{C} 6$ & $\mathrm{~d} 1$ & $\mathrm{~d} 2$ & d3 & $\mathrm{d} 4$ & d5 & $\mathrm{d} 6$ & $\mathrm{~d} 7$ \\
\hline 入 & 年 & 度 & \begin{tabular}{r|r} 
年 \\
1974 \\
\end{tabular} & 1974 & 1974 & 1977 & 1977 & 1978 & 1975 & (1983) & 1975 & 1975 & (1984) & 1980 & 1981 \\
\hline 成牛 飼 & & & 36頭 & 26 & 22 & 21 & 18 & 65 & 50 & (22) & 26 & 30 & (15) & 19 & 12 \\
\hline \multirow{3}{*}{$\begin{array}{l}\text { 飼料 作 } \\
\text { 面＼cjkstart積 }\end{array}$} & & 地 & $1.7 \mathrm{ha}$ & 1.2 & 2.0 & 1.0 & 0.3 & 1.3 & 2.0 & - & 1.2 & 1.4 & - & 0.2 & 0.3 \\
\hline & & 显地 & 11.8 & 8.1 & 5.9 & 6.6 & 9.4 & 15.5 & 13.0 & - & 8.8 & 6.9 & - & 3.5 & 6.0 \\
\hline & & & 13.5 & 9.3 & 7.9 & 7.6 & 9.7 & 16.8 & 15.0 & - & 10.0 & 8.3 & - & 3.7 & 6.3 \\
\hline \multicolumn{3}{|c|}{ 組合の飼料作面積合計 } & \multicolumn{6}{|c|}{$64.8 \mathrm{ha}$ (自作地 7.5 、受託農地 $57.3 \mathrm{ha}$ ) } & \multicolumn{7}{|c|}{$43.3 \mathrm{ha}$ (自作地 5.1 、受託農地 $38.2 \mathrm{ha}$ ) } \\
\hline
\end{tabular}

注：1）1986年時点の実態による.

2）（）は，構成員が酪農を廃止した年度と，その時の飼養頭数を示す.

それに対して，あう一つの機能として図 1 の П-2 に示すような組織体を越えた構成員のインフォーマル な活動が注目される7゙. 組織体の誘因が不足する場 合，その構成員は日常生活的な社会関係を基礎にし て，他の組織体の構成員汇連携相手を求めるととも少 なくない.しかむ，乙の構成員の間の日常生活的な社 会関係は，関係機関の働きのみでは不十分とならざる をえないような連携であってあ，それを継続させる機 能をあつ．そして，乙のようにして展開される構成員 のインフォーマルな活動には, 組織体内部のグループ 仲間を取り込んだかたちで，他の組織体とのグループ
的な連携を展開させたり，組織体の間の競争が決定的 なすのに陷らないで，今後の連携を可能にするパイプ 役的な機能が期待される.

以上のような分析の枠組みを検証するにあたって， 大型の稲作や飼料作の受託生産組織が, 現実に農地の 綮しい受託獲得競争をおてなっている富山県獂波市に 二組みの分析事例を求め，その比較を通じて，(1)日常 生活的な社会関係を基礎にした構成員のインフォーマ ルな活動が，組織体の内部や組織体を越えた局面でど のようにあらわれ，(2)そして，それぞれが属する組織 体自身の運営，管理や他の組織体との間の関係にどの 
図 2 分析事例の位置と農地の受託活動状況

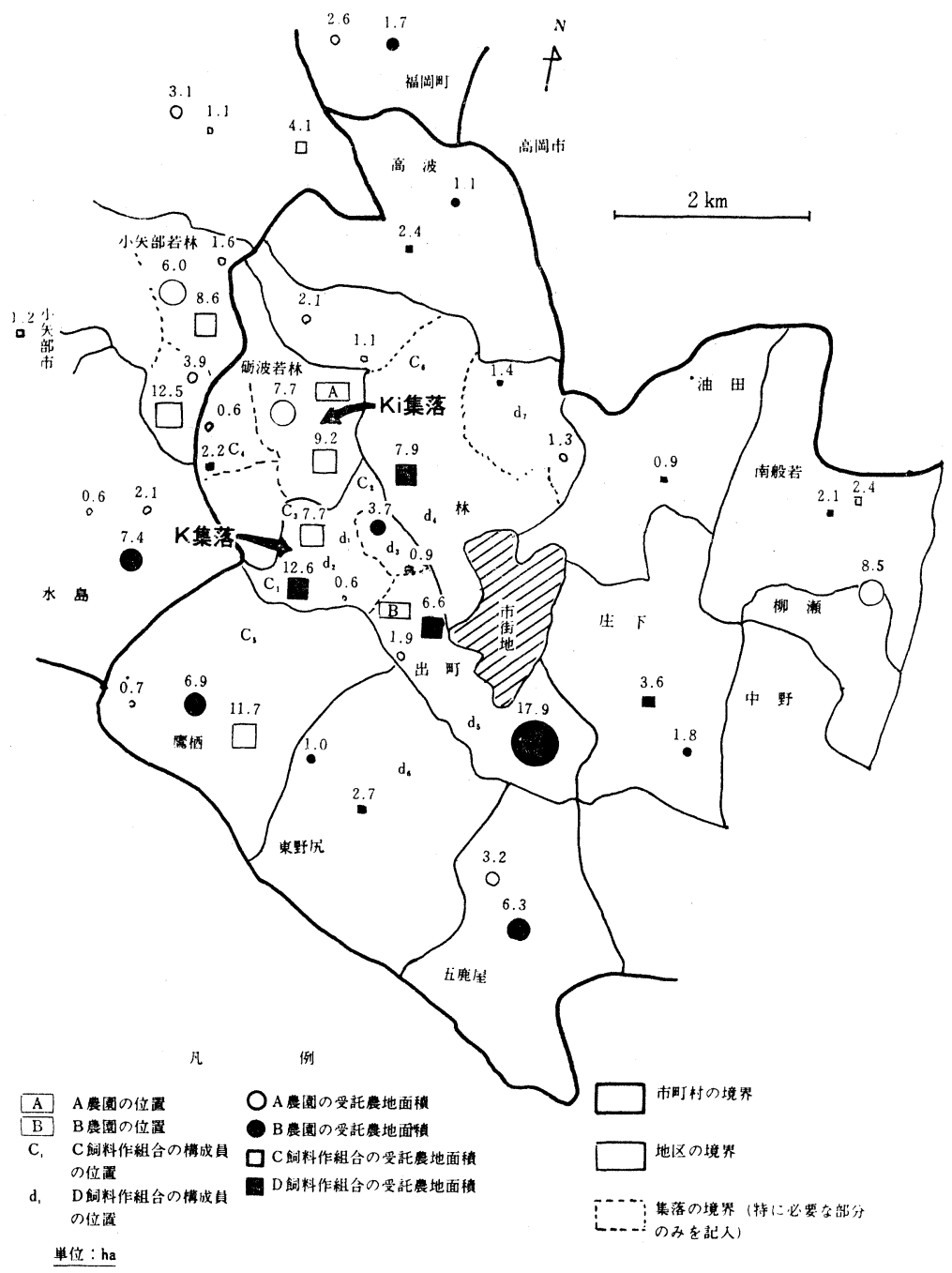

ような影響を与えるか明らかにする。

\section{2. 分析地域の農業の特徵}

碸波市は庄川扇状地のほぼ中央部に位置し, 農家戸 数は4, 173戸, 水田面積は4, 743haであり（1986年）, 散 居村とチューリップ生産で全国的に知られている，当 地域の農業の特徵は, 経営規模の大きい稲作の受託個 別経営や受託生産組織が多いととと，転作奖励金によ って, 稲作では支払いが難しい高水準の借地料を実現 し, 大きな武器にする飼料作の受託生産組織が展開し ていることである. 本稿で以下，分析対象としている
$\mathrm{A}$ と B の二つの農園は前者の代表例であり， C とDの 二つの飼料作組合は後者の代表例である.

まず，A農園は，それまであった地区ぐるみの機械 利用組合が解散した際に，その時のオペレーターであ った $a_{1}$ と $a_{2}$ によって1973年に結成され，その後 $a_{3}$ む 加わって，3人の共同経営となっている. 1986年時点 の農地受託は44.7haである。また，B農園は1971年に 個別経営として発足し，その後1973年に同じ地区内の 育苗受託を中心とする農家と「F耕作組合」を結成し た. しかし，当組合は組織運営に対する考え方の食い 遠いから1976年に解散し，B農園は再び個別経営とな 
り，雇用労働を中心にして運営されている，その農地 受託は1986年時点で49.1haである.

次に，飼料作の受託生産組織のうち, C 飼料作組合 は，転作施策の強化を背景にして， $\mathrm{e}_{1}$ を中心にして 1974年に 3 戸で発足し，その後1977年に $\mathrm{e}_{4}, \mathrm{e}_{5}$ が, 1978 年に $\mathrm{d}_{6}$ が加入し 6 戸となっている． 組合の飼料作面

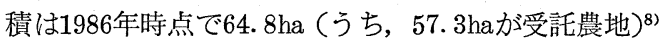
となっている．また，D飼料作組合は，1975年に5 戸 で発足し，その後，1980年と1981年に $d_{6} ， d_{7}$ が加入し 7 戸となったが，1983年と1984年に $d_{2} ， d_{5}$ 方酪農を廃 止して組合から脱退し， $d_{1}, d_{3}, d_{4}, d_{6}, d_{7}$ の 5 戸で 構成されている. 組合の 1986年 時点での 飼料作面積 は $44.3 \mathrm{ha}$ （うち，38.2 ha が受託農地）と比較的少な い.

これらの活動は隣接する小矢部市や高岡市などにも および，広域化がすすんでいる，その状沉をとくに農 地受託による経営規模拡大の経過という側面からみれ ば，図 2 のようである. とくに以下の点を指摘してお きたい。

第一は，小矢部市若林地区で，ほ場整備後のほ場を 巡って C 飼料作組合と $\mathrm{A}$ 農園が受託獲得競争を展開し て以来, ての競争は小矢部市若林地区から A農園の地 元集落（唚波市若林地区・K i 集落, 図 2 参照）にま でおよんでいるとと．その一方では， C 飼料作組合の $\mathrm{e}_{2}$ と A農園の間には個別的な 連携関係の展開もみら れること.

第二は，䃇波市出町地区での D 飼料作組合と B 農園 との間での農地の受託獲得競争で，とくにK集落（図 2 参照) に住むd 1 と隣り集落の B 農園の競争が緟し いとと. その一方で， $\mathrm{d}_{5} や \mathrm{~d}_{2}$ を空口にした $\mathrm{d}_{3}-\mathrm{d}_{4}-\mathrm{d}_{5}$ や $\mathrm{d}_{2}$ - $\mathrm{d}_{4}$ グループと B 農園とは連携関係むすすめて いるととである.

\section{3. 受託個別経営・受託生産組織内部での構 成員の連携・協力関係}

まず組織体内部における各構成員の経営行動をみて みよう。

\section{（1）稲作の受託個別経営・受託生産組織の場合}

1970年代に入って稲作の中型機械化体系が普及する が，A農園は，その体系を生かすために，個別経営の 枠を越えた組み作業というかたちで共同経営を展開し ている. その後, 受託規模の拡大とと屯に, 男子の常 時雇用者を入れて組み作業をおてない，1986年時点で 男子の常時雇用者は 2 人となっている。なお受託農地
図 3 飼料作組合内部での労働力交換

(C 飼料作組合の場合・1980年)

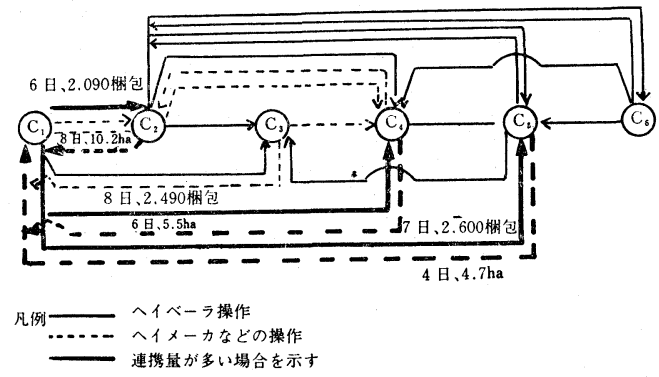

（D飼料作組合の場合・1979年)

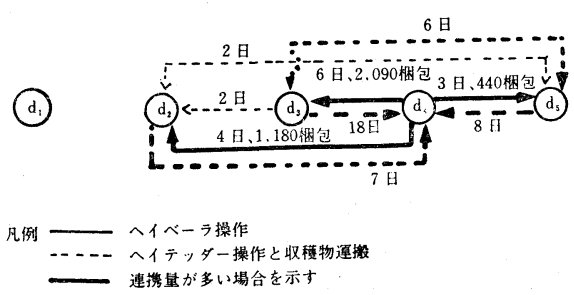

は，構成員各自が委託農家との間に有する日常生活的 な社会関係によって掘り起こされるが，共同経営のA 農園はそれを一括して引き受け, 利益は構成員に平等 に分配している.

一方， B 農園は，発足当初，中型機械化体系に対応 して, 男子の常時雇用者 1 人と組み作業をおてない, そのほか農繁期にはオペレーター雇用むおてなってい た. その後, 受託規模が拡大すると男子の常時雇用者 を 2 人に增やしている，また，経営主の妻は機械の補 助作業や水田除草などの手作業を担当し, その際に 2 〜 3 人の主婦を一時的に雇用している.

\section{（2）飼料作の受託生産組織の場合}

ア. C 飼料作組合の場合

受託面積の順調な拡大を背景にして， C 飼料作組合 はモアコンディショナーの導入など機械装備の充実を はかり、「イタリアンライグラス〜スーダングラス」と いう作付体系淿よって本格的な乾草生産をおてなって いる. その運営の機構をみると, 飼料作機械の共同所 有・個別利用を原則として, 構成員によっては, 操作 が難しい大型機械の利用を中心にして, 適宜, 飼料生 産上の学働力交換む ${ }^{9} お$ こなっている，また，受託農 
地は構成員個々の委託農家との接触によって確保され るが，それは組合に一旦集められ，その後，配分する というかたちになっている。

構成員のうち, 労㗢力交換が少ないのは，たとえ作 業が途れてあ自分でおてないたいという $\mathrm{e}_{3}$ と飼養規 模が65頭（1986年時点での成牛頭数）と大きく, 飼料 作面積をより多く必要としている $\mathrm{c}_{6}$ である． $\mathrm{c}_{6}$ は経 営主, 経営主の妻, 父が機械操作可能であり, 個別経 営内で組み作業をおてなっている。

それに対して, 労働力交換が多いのは $\mathrm{e}_{1}, \mathrm{e}_{2}, \mathrm{c}_{4}$, $\mathrm{c}_{5}$ である. 大型機械操作が河能な $\mathrm{c}_{1}$ と操作が 未熟な $\mathrm{c}_{2}, \mathrm{e}_{4}, \mathrm{c}_{5}$ の間では, 大型機械操作と中小型機械操作 ・収穫物運搬作業での労働力交換をおてなっている. 例えば， $\mathrm{e}_{1}$ が $\mathrm{e}_{2} ， \mathrm{e}_{4} ， \mathrm{e}_{5}$ 亿対してへイベーラーの操作 21 日間， 7,180 棝包をおてない，その見返りとして $\mathrm{e}_{2}, \mathrm{e}_{4}, \mathrm{e}_{5}$ が $\mathrm{c}_{1}$ に対してヘイメーカの操作 18 日間, 20.4haや収穫物運搬作業をおこなっている.

そして，乙のような飼料生産上の労㗢力交換のし方 は，構成員によって個別的に掘り起とされる受託農地 を組合内部で配分するかたちへと展開している．例え ば後揭図 4 のように， $e_{2}$ が，小学校時代加らの友人 で, 長年, Ki 暫集落の区長を務めるなどトップリーダ 一であった農家に接触をはかり，1978年に7.9haの受 託農地を確保している.このうち, $\mathrm{c}_{2}$ が 2.6 ha 引き 受け, 組合内部で飼料生産上の労働力交換が多い $\mathrm{c}_{1}$, $\mathrm{c}_{4} ， \mathrm{c}_{5}$ それぞれに $2.4 \mathrm{ha}, 1.4 \mathrm{ha} ， 0.3 \mathrm{ha}$ が配分されて いる. なお, その際に $\mathrm{c}_{2}$ 之労働力交換が少ない $\mathrm{e}_{3}$ に あ $1.2 \mathrm{ha}$ 配分されているが, この分は $\mathrm{c}_{2}$ が引き受けて きたほ場のうちであ離れたほ場であり， e 3 によって 個別的に作業がおこなわれている.

しかし，とのグループでおこなわ机る生産諸要素の 相互交換は必ずしも等価的でなく，年度によって交換 量あ異なっている，それであ継続しているのは， $\mathrm{e}_{1}$ 上 $\mathrm{c}_{2}$ の血縁関係にある，彼らは血縁関係を基礎にして互 恵的なかたちで, 生産諸要素の不等価, 不定量な相互 交換をおこない，そのような連携・協力のし方によっ て $\mathrm{e}_{4}$ や $\mathrm{e}_{5}$ という他の構成員む取り込み, $\mathrm{e}_{1}-\mathrm{c}_{2}-\mathrm{c}_{4}-$ $\mathrm{c}_{5}$ グループのかたちで互恵的な相互交換を継続させて いるのである．また，若手がいる $\mathrm{c}_{2}$ は大型機械操作 に興味をむっていたが，機栈が不足する組合の事情を 考えて, 中型機械操作に回っていた. このような $\mathrm{c}_{1}$, $\mathrm{c}_{2}$ が中心になっておてなう組合有機械のグループ的利 用は，機械を個別利用する $\mathrm{e}_{6}$ に対する他の構成員の 不満までも軽減させている.

\section{イ. $\mathrm{D}$ 飼料作組合の場合}

$\mathrm{D}$ 飼料作組合の飼料作機械は, 現在モアコンディシ ョナーやへイベーラなどの導入によって充実してきて いるが，特に1978年頃までは不十分であった．組合の 飼料作機㑘の所有・利用や受託農地の確保のし方は C 飼料作組合と同様である. 組合の運営の機構で異なる のは, C 飼料作組合が受託農地を組合の協議によって 配分するかたちをとっているのに対して，当組合は， その配分のし方を構成員それぞれの判断に任せている ことである.

まず，構成員のうち，飼養規模が50頭（1986年時点 の成牛頭数) と多い $\mathrm{d}_{1}$ は, 受託農地を自宅周辺に固 め, 個別経営内で妻と組み作業をおてなっている.とれ に対して, 農業労働力が 1 人の $d_{4}$ は大型機械操作を 担当し，大型機珹操作が未熟な $d_{2}, d_{3}, d_{5}$ が中小型機 械操作や収穫物運搬作業を担当するというかたちで労 働力交換をおてなっている．例えば，図３のように， $\mathrm{d}_{4}$ が $\mathrm{d}_{2} ， \mathrm{~d}_{3}, \mathrm{~d}_{5}$ に対してへイベーラの操作を13日間， 3,590 梱包扮てない，その見返りとして $d_{2}, d_{3}, d_{5}$ が $\mathrm{d}_{1}$ に対してへイメーカーでの反転, 集草や収穫物運搬 作業をそれぞれ7,18,8日間掞てなっている. そして, てのような飼料生産上の労動力交換のし方は, 構成員 によって個別的に掘り起こされる受託農地を他の成構 員へ配分するかたちへと展開している，例えば， $d_{4}$ が 遠距離の南般若地区で掘り起とした $1.5 \mathrm{ha}$ は $\mathrm{d}_{3}-\mathrm{d}_{4}-$ $d_{5}$ グループで共同作業がおこなわれ，収穫物で配分さ れている10.

しかし，乙の組合のグループでおこなわれる生産諸 要素の相互交換の多くも不等価，不定量である. それ でも継続しているのは， $d_{3}$ と $d_{4}$ の姻戚関係にある. $\mathrm{C}$ 飼料作組合の $\mathrm{c}_{1}, \mathrm{c}_{2}$ 同様沉, $\mathrm{d}_{3}$ 之 $\mathrm{d}_{4}$ 屯互恵的な汃 たちで，生産諸要素の不等価，不定量な相互交換を㧍 こない，その連携・協力のし力によって $\mathrm{c}_{4}, \mathrm{e}_{5}$ という 他の構成員屯取り込み，不足する組合有機㑘の有效利 用を笑現している.

\section{4. 稲作ट飼料作の受託個別経営・受託生産 組織の間の競争と連携の関係}

次に，組織体内部における構成員の連携・協力活動 を踏まえ，組織体を越えた構成員のインフォーマルな 活動が組織体の間の関係におよぼす影響をみてみる.

（1）A䨟園と C 飼料作組合との間の競争・連携関係 $\mathrm{A}$ 農園之 $\mathrm{C}$ 飼料作組合との間の農地の受託獲得競争 は1977年心ら始まっている，当時，小矢部市若林地区 
図 4 A農園と C 飼料作組合の間の競争, 連携関係

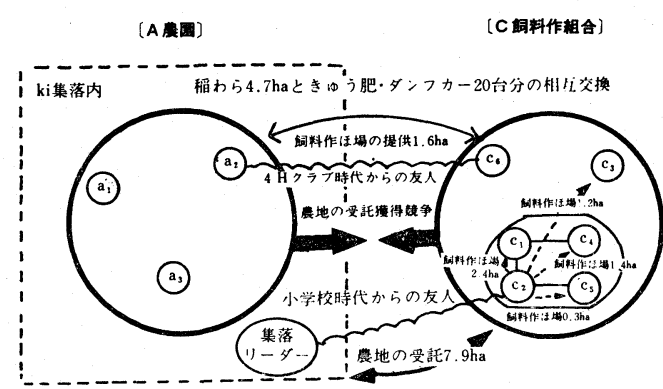

凡例

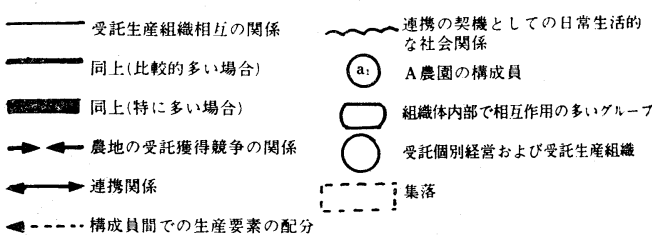

でほ場整備がすすめられ，A農園は工事が終了したと ころから受託を始めていた．1975年，すでにA農園の 受託は, 農地受託 3 戸，1.8ha と, 部分作業受託 2 戸， $0.8 \mathrm{ha}$ となり，その後少なくとも約 $7 \mathrm{ha}$ の農地受託が 予定されていた。一方， $\mathrm{C}$ 飼料作組合む同様のねらい をむち，構成員の $e_{1}$ は親戚である当該地区の土地改 良区理事長への接触をはかっていた。ところが，ての 頃からほ場整備事業にとあなう転作の義務付けが強化 されるようになり，当地区では稻作面積を縮小せざる をえなくなった，さらに，飼料作物を栽培した場合， 転作奖励金が作り出す実質的に支払い可能な借地料水 準が高いこともあって，A農園が契約することになっ ていた受託農地の多くがC 飼料作組合へ移ってしまっ た。ちなみに，1977年に㧈ける当地区での稲作の場合 の借地料は 3 年契約で $10 \mathrm{a}$ 当たり $135 \mathrm{~kg}$ (政府米 1 類 1 等の単価で換算，以下同様）であったのに対して，C 飼料作組合の借地料は裏作奖励金の受取り額を工夫 し，226kgとなっていた。

それ以来，乙の上うな受託獲得競争はいくつかの他 の地域であ生じ， $\mathrm{A}$ 農園の地元であるK $\mathrm{i}$ 集落（農家 数 85 户，水田面積128ha，図 2 参照)にもおよんでい る. 当集落での転作対応は，A農園の自作地のほか, 受託農地や部分作業受託ほ場も含めて，集落全体でブ ロックローテーションがすすめられた，その際に，C 飼料作組合は7.9haの受託 農地を確保している. 1978 年当時, 殆どの転作ほ場を外部者の C 飼料作組合が受 託していたてとから，A農園が大きな収入源としてい た水稲の部分作業受託が減少した. 当集落での部分作 業受託は1976年に37.4haであったのが，1979年には26 .8ha亿減少している，そのため，A農園はC 飼料作組 合に対抗して，1981年から，機戍化体系が不十分にも かかわらず，市内の他の大型の稲作受託生産組織に先 駆けて大豆栽培に取り組み， $5.5 \mathrm{ha}$ の大麦〜大豆栽培 を始めている。

このように，双方の組織体は農地の受託獲得競争を 展開しているが, その一方, 構成員の $\mathrm{e}_{6}$ は， $\mathrm{A}$ 農園 の $\mathrm{a}_{2}$ と $4 \mathrm{H}$ クラブ時代から友人であったととを契機 にして，C飼料作組合に加入する以前の1975年頃から 連携をはかっている.1978年に，双方は4.7haの稲わ らと小型ダンプカー約 20 台分のきゅう肥との相互交換 を抢てなったり， $\mathrm{e}_{6}$ がA 農園から転作ほ場 1.6haの配 分を受けるなどの連携がおてなわれている．飼養頭数 が65頭と多い $\mathrm{e}_{6}$ は，組合に加入しても配分を受ける 面積が不十分なととああって，A農園との連携はその 後手続けられている。

しかし，その連携の内容をみると問題も多く，例え ば， $\mathrm{e}_{6}$ へ飼料作用に提供したほ場で，A農園は再び 稲作をおこなったが，倒伏が目立ったり，中間生産物 の相互交換屯年次的に不安定で， $\mathrm{e}_{6}$ の稲わら収集約 5 haに対して, きゅう肥の提供が小型ダンプカー 6 台 分にとどまるとともみられた．とのように，一般には 連携が中止されるような状況にあっても, 彼らの日常 生活的な社会関係を紐帯にして連携を継続させてい る.

次に， $\mathrm{e}_{6}$ と $\mathrm{A}$ 農園との個別的な連携活動が，双方の 組織体の間の関係におよぼしている影響をみてみる。 $\mathrm{e}_{6}$ は組合内部で個別的傾向が強いため， $\mathrm{A}$ 農園との連 携は組合内部の他の構成員までにはおよばず，個別的 な連携にとどまっている。

しかし，乙の個別的な連携活動は，双方の組織体の 競争関係が決定的なものに陷らないような役割を果た している．例えば， $\mathrm{C}$ 飼料作組合は $\mathrm{A}$ 農園の構成員が 住む $\mathrm{K}$ i 集落へ進出し，A農園の受託ほ場であ飼料栽 培をおてなっているが，その際に $\mathrm{e}_{6}$ を通してA農園 は C 飼料作組合にトラクタのわだちが大きくならない ように注意するととを約束させている。すなわち，乙 の上うに個別的に親しい $a_{2}$ と $c_{6}$ は, それぞれの組織 で受託農地の掘り起しや利用の際にトラブルが生じた 
図 5 B農園と D 飼料作組合の間の競争, 連携関係

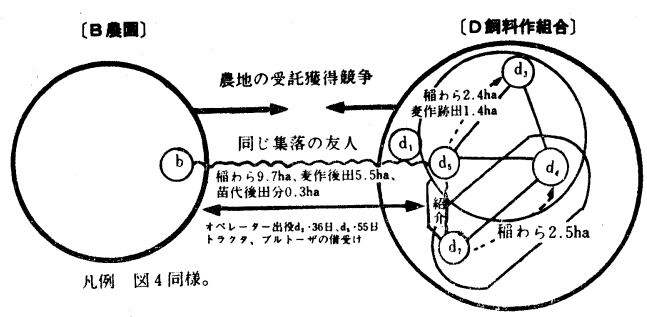

場合, その抗議内容を互いの構成員に事前に知らせ, 決定的な競争関係に陥らないような役割を果たしてい る.

（2） B 農園と D 飼料作組合との間の競争・連携関係 嘱波市出町地区のK集落（農家数 64 戸，水田面 積 94. 0ha, 図 2 参照)でみられる B 農園とD 飼料作組合と の間の農地の受託獲得競争は, 同集落に酪農家が偏在 しているととで，より一層厳しいものとなっている. $\mathrm{K}$ 集落には C 飼料作組合の $\mathrm{c}_{1}, \mathrm{c}_{2}, \mathrm{e}_{3}$ や $\mathrm{D}$ 飼料作組合 の $d_{1}, d_{2}$ が住んでいるが，そこにB農園が進出する ことによって農地の受託獲得競争が生じ, とくにB農 園と $d_{1}$ との間で緟しい。

K集落では，1972年からほ場整備工事が始められた が，B農園は工事が終了したほ場から逐次，受託を始 め，1975年には 8 戸，5.4haの部分作業を受託し，今 後に拈ける重要なテリトリーの一つにしようとしてい た. しかし，その頃からB農園に対して，とくに $d_{1}$ による排厅行為が強くなり，B農園が確保してきた部 分作業受託のうち 5 戸，1.4haの分が $\mathrm{d}_{1}$ 一移動すると とあに，委託を中止する農家屯 3 戸，1.9ha あらわれ てきた.

その結果，K集落での B 農園は新しく受託した分を 含めても，農地受託 1 戸， $0.6 \mathrm{ha}$ と部分作業受託 2 戸， 2, 6ha 減少している. K集落へのB農園の進出か阻止 された主な要因として， $d_{1}$ の集落内における濃密な社 会関係の活用之転作奖励金尤って実質的に支払える 借地料が高かったてとがあげられる，当時，K集落で はほ場整備直後の水田の場合, 借地料は $120 \mathrm{~kg}$ が一般 的であったが， $d_{1}$ は転作奖励金の活用によって $180 \mathrm{~kg}$ （約50,500円）の借地料を提示している. それに対し て, B晨園は「飼料作後の水田は水榉栽培がおてない にくいととから，借地料は90kgにしたい」と，競争相 手の $d_{1}$ を意識して対抗策を打ち出した．とのような
双方の農地の受託獲得競争は $\mathrm{K}$ 集落のほか, その周辺 集落にもおよび，乙の場合は $d_{1}$ のか $d_{3}, d_{4}$ を含ん だ競争となっている.

このように，双方は農地の受託獲得競争を展開する 一方, $\mathrm{D}$ 飼料作組合の $d_{5}$ と B 農園主の親しい間柄を 基礎にして労働力, 機械, 農地, 中間生産物など多面 的な相互交換を，D飼料作組合内部で飼料生産上の労 働力交換が多い他の構成員を取り込九だ $\mathrm{d}_{3}-\mathrm{d}_{4}-\mathrm{d}_{5}$ や $\mathrm{d}_{2}$ 一 $\mathrm{d}_{4}$ というグループのかたちでおてなっている. そ の経過をみると, 個別経営の B 農園は受託規模が拡大 にするつれて，春の耕耘，田植えや秋の杊取時に労働 のピークが大きくなり，その対応が当面の課題となっ ていた．B農園はその対応として，1974年に同じ集落 で小さい頃からの友人であった $\mathrm{D}$ 飼料作組合の $\mathrm{d}_{5}$ に 機械オペレーターや収檴物の運搬作業の手伝いを依頼 するととあに， $d_{5}$ を通して $d_{2}$ にも機械オペレーター を依頼している．乙のようなB 農園への出役は1980年 で， $d_{2}$ が36日， $d_{5}$ が55日となっている.

そしててのととを契機にして， $d_{2}$ や $d_{5}$ はD飼料作 組合内部では調達が不十分な生産要素を B 躃圖に求め ている. 彼らはB農園からトラクターやブルトーザー を借りたり，受託ほ場の稲わら 9.7 haや麦作後田 5.5 ha，苗代後田0.3haの配分を受けている. しかし，その 連携の内容をみると，年次的に変動があったり，本来 は成立しにくいと思われる連携のケースむ少なくな い、にもかかわらず，それを実現し，継続させてい る. 例えば，水稻の刈取作業は不安定な秋の天候をに らみながら，能率的に打てなうことが求められる。 そ のため他の稲作受託生産組織であれば，頼んであ実現 しないと思われるが， $d_{5} や d_{2}$ は牛舎の敷わらにあ 活用できる長わらを確保するため，杊取能率が低下す るにもかかわらず，自脱型コンバインのカッターをは ずしての稲わら収集をB農園主に頼夕，実現してい る.

このような $\mathrm{B}$ 農園との連携は $\mathrm{d}_{2}$ や $\mathrm{d}_{5}$ にとどまらず に, 組合内部で飼料生産上の学働力交換が多い $d_{3}$ や $\mathrm{d}_{4}$ 屯取り込んだグループ的なものとなっている.

例えば，図 5 の上うに， $d_{2} や d_{5}$ が $B$ 農園から配分 を受けた分のうち，さらに稻わら2.4ha分と麦作後田 1. 4 haが $\mathrm{d}_{3}$ へ, 稲わら2.5ha分が $\mathrm{d}_{4}$ へ配分されている. 乙の場合, $d_{3}$ や $d_{4}$ は $\mathrm{B}$ 農園之農地の受託獲得競争を おてなっているのであるが, $d_{5} や d_{2}$ がパイプ役とな って, B農園からの稲わら調達や機械借用を実現して いる. 
この経過事実は， B農園と競争関係にある $\mathrm{d}_{3} や \mathrm{~d}_{4}$ との間にも「受託ほ場を確保する際, 相手が受託して いる農家からの委託依頼であった場合に出来るだけ避 ける」というかたちでの暗黙の了解事項を次第に形成 させていた. しかし，B農園とのパイプ役になってい た $\mathrm{d}_{5}$ や $\mathrm{d}_{2}$ が1983年から1984年にかけて酪農をやめて 兼業農家になり，組合から脱退した．乙のととから， パイプを失った B農園とD飼料作組合の間には，連携 がみられなくなり，競争関係のみとなっている.

\section{5. まとめ}

北陸水田地帯では稲作と飼料作の受託生産組織の間 の連携を促そうと, 生産技術開発や行政施策がすすめ られてひさしい. しかし，資本財として措定しえない 農地や天候に規制されざるをえない農作業, 農業生産 という農業がもつ特徽は, 関係機関がこれらの間の連 携を経済的あるいは制度的に推進しようとする際の阻 害要因となっている.

このような生産現場の根底にある問題を解決する糸 口の一つは, 濃密な日常生活的な社会関係があつエネ ルギーを核にした農業者のインフォーマルな活動に見 い出すととができる.すなわち，一般には難しいと思 われている連携であってあ，農業者のインフォーマル な活動は, 発生, 介在する互いのコンフリクトをそこ に融合させ，彼らの連携を可能にしている，

まず, とのような農業者のインフォーマルな活動を 基礎にした一連の連携・協力のし方が，組織体内部の 一部の構成員でおこなわれた場合，そのエネルギーは 他の構成員をも取り込んで，組織内グループとして機 械や労働力の相互交換のほか, 構成員個々がかく得し てくる受託農地の配分まであ可能にしている. てのと とが結果的に，構成員へ与える誘因が不足がちになる 組織体自身の運営，管理面を補強している.

他方, 農業者のインフォーマルな活動を基礎にした 一連の連携・協力のし方が，組織体を越えておてなわ れた場合，そのエネルギーは競争関係にある組織体の 間のパイプとなり，競争関係の激化を事前に防いで, 今後における連携の余地を残すような機能を示してい る.さらに，そのエネルギーが組織内グループの活動 と結合した場合，組織体の間が競争関係にあっても， その中にグループ的連携を実現し，継続させる機能が 検証できる.

注 1) 本稿では, 農地法, 農協法, 農地利用增進法等
の法的根拠に基つく農地貸借や全作業受委託のほ か, 法的根拠に基つかないが, 実質的には農地貸 借がおてなわれている場合も含めて「農地の受委 託」として，部分的に農作業の受委託がおとなわ れている場合を「部分作業受委託」として表現す る.

2) 受託生産組織の構成員は, 経営規模拡大のため に必要な種々の生産要素の確保をめぐって競争を 起こすが, 本稿では競争のうちでも, 農地の受託 をめぐる競争関係を分析の対象とする.

3）本稿で分析の対象にしたのは1986年までである が, それ以降, 礪波市では農地の受委託面積が増 えている、しかし，稲作の受託個別経営や受託生 産組織でみると, その増加は, 従来加ら確保して きたテリトリーの中でみられる. 一方, 飼料作の 受託生産組織は大麦, 大豆作面積の增加によっ て，飼料作面積を減少させてきている。乙のよう に, 双方は互いにテリトリーの確保, 維持をめぐっ て厳しい競争を展開しているのにかわりがない。

4) C.I.バーナード・田杉競監訳『経営者の役 割』1956年, ダイヤモンド社, 124〜133頁.

5 ）金沢夏樹「部落の理論的考察」『経済的土地分 級』1973年, 東大出版会, 161 162頁.

6)このととに関しては,『内部組織の経済学』の中 間組織から整理される. 中間組織の場合, 経営体 や組織体間のコンフリクト（矛盾の発生と対立） の発生への対応が問題之されている. それに対応 するための中間組織における経営戦略は, (1)中央 の総司令部の回りに存在し，それと縦系列下にあ る下位単位の間の中でっくる関係(2)継起的な相互 依存性の中でっくる関係 (3)互恵的 (re-ciprocal) につくる関係の三つのタイプに整理される，ての うち, (1)のタイプは, それぞれの関係をフォーマ ル的に関係付ける場合であり，権限によってコン フリクト発生への対応をはかろうとする形であ る. 例えば，強力なリーダーシップの下でおてな われる生産組織の運営, 管理である. 次に, (2)の タイプは, 互いの経営展開にあたって, 相手の経 営の存在が不可欠であるという状況を作り上げ, コンフリクト発生への対応をはかろうとする形で ある. 例えば, 他地区へ進出して, 進出先の競争 相手からの排斥行為を回避しようと, 進出先の農 家との相互依存関係をつくる形である。（伊丹敬 之, 今井賢一『内部組織の経済学』1982年, 東洋 経済新報社, 127頁. 加護野忠男『経営戦略論』 1985年, 有斐閣, 113 131頁)

7) 拙稿『生産組織間の連結之条件・東畑四郎記念 奖励事業報告 No. 2 』1984年, 農政調查委員会, 23 $\sim 27$ 頁. 
8) 割当された転作面積を消化しょうと, 集落から 頼み込まれた場合の多くは, 当初から集落側の経 費負担でおこなわれ，形のみの飼料作物栽培とな り，単収は二の次になっている，そのととから， 本稿では, この場合の分は受託農地面積から除い た.

9 ）労働力が経営間でやりとりされる形態は, 一般 に(1)共同作業(2)ゆい(3)手間替え並びに, (4)共同作 業とゆいを含んだかたちの四つに仕分けされる． ここでは，(2)の「ゆいが中心となっているが, これをあえて「労㗢力交換」と表現したのは, 手 作業段階での裸の労㗢力のやりとりがイメージさ れる「ゆい」では，今日の機械力を背景とした労 働力のやりとりを特徴付けられないのである。し たがって，ここでいう「労働力交換」は飼料作に 関する一連の高度な機械利用を推進する労働力交 換の意味である。

10）とのような $d_{5} や d_{2}$ をパイプにした連携のし方 は, 組合内部での労㗢力交換のグループの編成が
変化しても, その変化したグループとB農園との 間でみられた。

参考文献

〔1】青井和夫ら『集団, 組織, リーダーシップ』 1977年, 培風館, 84頁.

[2]伊藤忠雄「受託組織の発展条件に関する一考 察」1980年, 関西農業経済学会誌, 21〜26頁.

〔3]石原武政『マーケティング競争の構造』1982 年, 千倉書房, 170頁, 204頁, 235頁, 263頁.

〔4]尾高邦雄『現代の社会学』1968年, 有斐閣, 289 295頁.

〔5]花田仁伍「資本の法則と土地所有の法則・農業 資本の法則」『現代日本資本主義経済におりる農 業問題』1976年, 御茶の水書房, 第 3 章第 2 節.

[6]拙稿「稲作受託経営展開之社会関係の活用」 1991年, 中部農業経済学会誌，22～27頁.

（筆者・富山県庁普及指導課） 